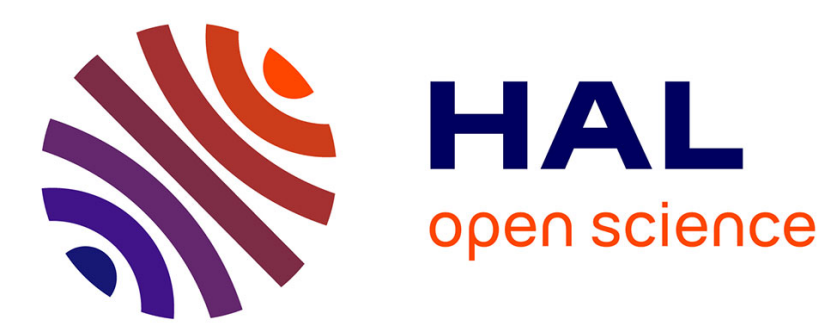

\title{
Teaching Physics Using Appropriate Technology Projects
}

\author{
Joshua Pearce
}

\section{To cite this version:}

Joshua Pearce. Teaching Physics Using Appropriate Technology Projects. The Physics Teacher, 2007. hal-02120517

\section{HAL Id: hal-02120517 https://hal.science/hal-02120517}

Submitted on 6 May 2019

HAL is a multi-disciplinary open access archive for the deposit and dissemination of scientific research documents, whether they are published or not. The documents may come from teaching and research institutions in France or abroad, or from public or private research centers.
L'archive ouverte pluridisciplinaire HAL, est destinée au dépôt et à la diffusion de documents scientifiques de niveau recherche, publiés ou non, émanant des établissements d'enseignement et de recherche français ou étrangers, des laboratoires publics ou privés. 


\section{Teaching Physics Using Appropriate Technology Projects}

Joshua M. Pearce, Clarion University of Pennsylvania, Clarion, PA

A ppropriate technologies able to be easily and economically constructed from readily available materials by local craftspeople have a central role in the alleviation of poverty in the developing world. However, research and development of these technologies are generally apportioned relatively modest support by the developed world's institutions, in part because the operation of many of these appropriate technologies is dependent on relatively well-understood science accessible even to introductory college physics students. This paper describes a project-based assignment used to capitalize on this opportunity to motivate students to learn physics by offering them a chance to make concrete contributions to the optimization of appropriate technologies for sustainable development.

Nonphysics majors such as students majoring in biology or premedicine can have a low motivation to learn physics because 1) they do not readily connect physics instruction to their own lives or professional careers, 2) many are intimidated by advanced mathematics and the reputation of physics as being math intensive and rigorous, and 3) mathematical abstractions of physical reality lie outside of their interests in life systems and "helping people." This low motivation can hinder optimal student learning in several ways. This paper focuses on preliminary results of teaching experiments run in five algebra-based physics classes ( -30 students/class), which included structured, selfdirected laboratories based on solutions to developmental problems using "appropriate technology" to motivate biology students to learn physics.

\section{The Need for Sustainable Development}

Despite global progress, the need for development is as great now as it has ever been, with The United Nations having labeled this the "Decade of Education for Sustainable Development" (2005-2014). ${ }^{1}$ However, future development cannot simply follow past models of economic activity, which tended to waste resources and produce prodigious pollution. In the developed world we are now paying to clean up the mess and enormous quantities of valuable resources have been lost for future generations. The developing world needs ways to achieve economic, social, and environmental objectives simultaneously. We need to improve the efficiency with which we use resources. In order to meet this goal, international cooperation in overcoming environmental problems is necessary to help the world's poorest people develop as we move toward a more global society.

The global picture is sobering: ${ }^{2}$

1) Around 1.2 billion people live on less than $\$ 1$ a day and 2.8 billion people live on less than $\$ 2$ a day.

2) Nearly 1 billion people in the world lack access to improved water sources (i.e., safe drinking water and basic sanitation).

3) More than 30,000 children under the age of five die each day from preventable causes.

This enormous challenge to our generation is growing - the world's population will probably increase by 
about half (another 3 billion people) by 2050. This is the challenge of sustainable development.

Although a body of academic work devoted to sustainable development has begun to amass, ${ }^{3}$ much of the research conducted at universities is not specifically designed to help resolve the developing world's problems. For example, in 1990 less than 10\% of the world's health research was being applied to the health problems in developing countries, where $90 \%$ of the avoidable burden of health problems was to be found. ${ }^{4}$ Although research expenditures have increased, this "10/90 gap" remains and has become a symbol of inequity in global expenditures on research. ${ }^{5}$ The vast majority of resources, both mental and economic, are concentrated on scientific and technological research focused on quantifying sustainability indicators and the frontiers of science and social theories_-pushing the envelope on large and complex problems. The less grand questions of how to actually implement sustainable practices across a range of contexts, particularly for small-scale appropriate technologies or applications in developing nations, is often apportioned significantly less resources for inquiry.

\section{Appropriate Technology}

In this paper, appropriate technologies are defined as those that must be able to be easily and economically constructed from readily available materials by local craftspeople. Appropriate technologies must meet environmental, cultural, economic, and educational resource constraints of the localized community. Although some limited research has been done on a number of appropriate technologies, the diffusion of these innovations has greatly lagged behind the demand in the developing world.

Fortunately, a consortium made up of universities and nonprofit organizations is forming to develop a solution. They are collaborating on an Enabling Innovation Initiative, ${ }^{6}$ which is currently building a free-access database to warehouse basic plans for appropriate technologies that contribute to sustainable development. For example, a consortium member recently demonstrated an appropriate technology known as the "rocket stove" in Haiti. Due to a clever application of thermodynamics, the rocket stove is more efficient than a traditional " 3 -stone" fire. It can bring water to a boil in less than half the time using approximately one-third the wood. This has implications for cost savings on fuel and positively affects rates of deforestation and erosion. Most importantly —a rocket stove can be made from waste tin cans!

\section{Opportunity for Physics Students}

The creation of the Enabling Innovation Database provides an opportunity for college students to directly contribute to sustainable development. A quarter of a century has now passed since Peter Logan in his seminal paper suggested physics could play a major role in sustainable development by contributing to the interdisciplinary field of appropriate technology. ${ }^{7}$ Yet the majority of appropriate technology research has been accomplished by time-consuming trial-and-error methods in the field by individuals without technical backgrounds. The ability of undergraduate students to solve such real-world problems is generally neglected. ${ }^{8}$ Yet college students are both capable and enthusiastic real-world problem solvers if they are freed to undertake structured self-directed assignments. The operations of many of these appropriate technologies are governed by physical laws taught in introductory physics classes. In addition to a solid foundation in the scientific method and physics principles learned in university introductory physics courses, students have access to the scientific literature in the university libraries, which is often not available to developmental agents in the field. The students also have access to some relatively sophisticated scientific equipment (e.g., computer-integrated thermocouples), which can be used for controlled studies of appropriate technologies. By studying appropriate technologies, students can perform the basic research necessary to optimize such devices and gain a better understanding of physical principles.

Many simple appropriate technologies could be made into hands-on demonstrations of basic physical principles:

- Mechanics: water pumps (e.g., seesaw, sleeve, tire/ pvc, and water rams), brick making, rammed earth construction, and percussion drills for wells.

- Thermodynamics: evaporative cooling, stoves/ovens, solar cookers, food dehydrators, and other passive solar devices.

- Optics: solar water purifiers and reflectors (e.g., compound parabolic concentrators). 
- Electricity/Magnetism: balance of systems and basic electronics for micro-hydro, solar photovoltaic, and micro-wind power.

\section{The Assignment: Appropriate Technology Projects}

In order to amass the benefits of self-directed learning $^{9}$ and the motivational factors involved in this opportunity, I assigned an end-of-the-semester project that required students to design a physics lab around an appropriate technology of their choice. Students, working alone or in groups of two, identified and researched the technical specifications of an appropriate technology that interested them through library research, examples from former students, my own collection of books and articles, and the Internet.

They were then asked to write a project proposal based on the specifications necessary for input into the Enabling Innovations Database, which is organized by fields (excluding rankings and versions) that include:

- Title of the device or system

- Abstract describing the function of the device or system

- A list of keywords to describe the device or system. The key words will be used in a search engine in order to locate the device or system

- Developmental needs addressed (e.g. food, heat, electricity, clean water, health care, etc.)

- Materials needed for fabrication of device and alternative materials if they are not available

- Tools needed for fabrication of the device and alternative tools if they are not available

- Skills and knowledge necessary to make the device

- Technical specifications including a drawing or picture of the device-detailed enough to ensure that someone could construct the device from the description alone

- Estimated costs

- The sources of information

Projects that were within the scope of the assignment were approved. Then students constructed functional prototypes of their devices and designed a laboratory around their device to test at least one physical principle. The laboratory write-ups were modeled off of the conventional laboratories we completed all year in class:

a. Introduction-purposes

b. Setup

c. The physics theory/principle(s) to test

d. Procedure: The procedures include step-bystep laboratory instructions for the experiment, which ideally were detailed enough that a physics student could do the lab without assistance

e. Data and formula sheet for the laboratory

f. Questions

g. Proposed future research to optimize the device

\section{Outcomes and Conclusions}

The last week of classes the students brought their devices and lab write-ups to class. They exchanged labs and completed their peer's lab similarly to a standard laboratory. The students provided feedback to their peers to improve and make the lab write-ups more clear. Finally, the write-ups were augmented following the suggestions of their colleagues and emailed to the instructor.

Students chose a wide range of appropriate technologies and physics principles to study. Some interested in mechanical properties built a bicycle-powered table saw and another group a vertical-axis flexible-blade windmill. Many students explored basic thermodynamics and heat transfer by constructing a plethora of individual-scale or village-scale solar powered devices such as: water pasteurizers, dehydrators, ovens, and stills. The most promising of these projects, like those listed above, have been stored to assist future students in incrementally improving the designs. Most students based their projects on designs from the literature and began the long task of optimizing the devices. However, some students interested in electricity challenged themselves by trying to develop both new types of batteries and solar photovoltaic cells from low-cost materials. These projects, the first based on eggshells and urine and the latter on widely available titanium dioxide and indigenous berry dyes, led to independent study classes, where the students are working to develop the modest successes (functioning devices) from their novel ideas into practical devices and submit to appropriate undergraduate journals. ${ }^{10}$

Overall it appeared that the appropriate technology project was an enormous success as determined by 1 ) observed increase in student motivation to learn phys- 
ics, 2) observed time invested by students on projects outside of structured class, 3) student comments on end-of-semester instructor evaluation forms, and 4) a modest increase in pre/post-exam grades. The class average on an exam after the project was larger than the average of the exams before the project (with an average of approximately one-half letter grade) for four out of the five classes and remained the same for the fifth class. It is interesting to note that the largest improvement was observed in the academically poorest class, whose class average increased by $12 \%$ (from a low D to a $\mathrm{C}$ ), while the highest achieving class showed no improvement. These preliminary results indicate that these projects are most beneficial to those students who are having difficulty learning physics.

The students were encouraged to choose projects that would help them gain a better understanding of physics concepts they were having trouble understanding. Many of the students chose projects that helped them gain an in-depth understanding of a concept they had been formerly struggling with. On the lab day each student was in essence a teacher (and thus highly motivated to learn and understand the material) as he/she helped peers complete the appropriate technology laboratory. Utilizing physics as a service has proven successful in the past. ${ }^{11}$ This method proved so successful that last semester I included two rotations rather than one. The projects were extremely motivating to the students in part because they had an opportunity to contribute to a social service. In this case the effect may have been augmented because the majority of the students that completed the projects were upper-level biology majors headed for medical school who intrinsically favor completing projects with a social benefit. The students had an overwhelming positive attitude toward the assignment, tending to gain in-depth understanding of science issues and concepts outside of their individual fields of study, as is generally observed for self-directed projects. ${ }^{?}$

\section{References}

1. United Nations Educational Scientific and Cultural Organization, United Nations Decade of Education for Sustainable Development (2005-2014), Education for Sustainable Development (2006). Available: http://www. unesco.org/education/desd/.

2. United Nations Development Programme, Human Development Report 2001: Making New Technologies Work for Human Development (Oxford University Press, New York, Oxford, 2001). Available: http://hdr.undp.org/ reports/global/2001/en/.

3. See for example: S.M. Lélé, "Sustainable development: A critical review," World Dev. 19, 607-621 (June 1991); D. Mebratu, "Sustainability and sustainable development: Historical and conceptual review," Environ. Impact Assess. Rev. 18, 493-520 (Nov. 1998); J. Elliott, An Introduction to Sustainable Development, 2nd ed. (Routledge, New York, 1999); J. Sayer and B. Campbell, The Science of Sustainable Development: Local Livelihoods and the Global Environment (Cambridge University Press, Cambridge, 2003); P. Rogers, K.F. Jalal, and J.A. Boyd, An Introduction to Sustainable Development (Harvard University Press, Cambridge, MA, 2006).

4. Commission on Health Research for Development. Health Research: Essential Link to Equity in Development (Oxford University Press, New York, 1990).

5. Monitoring Financial Flows for Health Research 2005: Behind the Global Numbers, edited by M. A. Burke and A. de Francisco (Global Forum for Health Research, Geneva, Switzerland, 2006).

6. For more information about Enabling Innovation, contact Scott Albritton at thinkglobally@gmail.com.

7. P.F. Logan, "Physics in appropriate technology," Phys. Technol. 11, 187 (1980).

8. J.M. Pearce and C. Russill, "Student inquiries into neglected research for a sustainable society: Communication and application," Bul. Sci. Tech. Soc. 23(4), 311 (2003).

9. J. M. Pearce, "The use of self-directed learning to promote active citizenship in science, technology and society classes," Bul. Sci., Tech. Soc. 21(4), 312 (2001).

10. For example, the International Journal for Service Learning in Engineering (IJSLE) is a peer-reviewed electronic journal offered free, semi-annually over the World Wide Web. The journal welcomes manuscripts based on original work of students and researchers with a specific focus or implication for service learning in engineering, engineering entrepreneurship in service, or related service learning pedagogy.

11. T.G. Hollinsworth and M.A. Day, "Physics as service," Phys. Teach. 38, 472 (Nov. 2000).

PACS codes: 01.55.+b, 01.75.+m, 01.40.gb



Joshua Pearce is an assistant professor of physics at the Clarion University of Pennsylvania, where his research focuses on applied sustainability and the physics of solar photovoltaic devices and materials.

Physics Department, 106 Peirce Sci 1232; jpearce@clarion.edu 